\title{
Investigation on the Labor Rights and Legal Protection of Part-time Job for College Students
}

\author{
Luning Pang ${ }^{1, *}$
}

${ }^{1}$ The University of Melbourne, Melbourne, Australia

*Corresponding author. Email: PangLooning@163.com

\begin{abstract}
Nowadays, the part-time job for college students has become an increasingly common phenomenon. However, in the course of part-time jobs, college students are vulnerable to various violations of intermediaries and employers due to their low vigilance and lack of awareness of rights protection. At present, for the protection of the labor rights of college students, the common practice is to seek the protection of arbitration institutions. But the role and protection of the current law are limited. It is necessary to expand the protection scope of the labor law, protect college students as a special subject in the labor law, and improve the current system to protect their legitimate rights and interests.
\end{abstract}

Keywords: part-time job for college students, investigation of causes, legal protection

\section{INTRODUCTION}

\section{A. Investigation background}

Today's society is developing more and more rapidly, on the other hand, it also puts forward higher requirements for the group of college students. The university has relatively few courses and more maneuvering time, which provides college students with the necessary conditions for part-time work.

The part-time job for college students refers to the act of college students using their spare time to provide

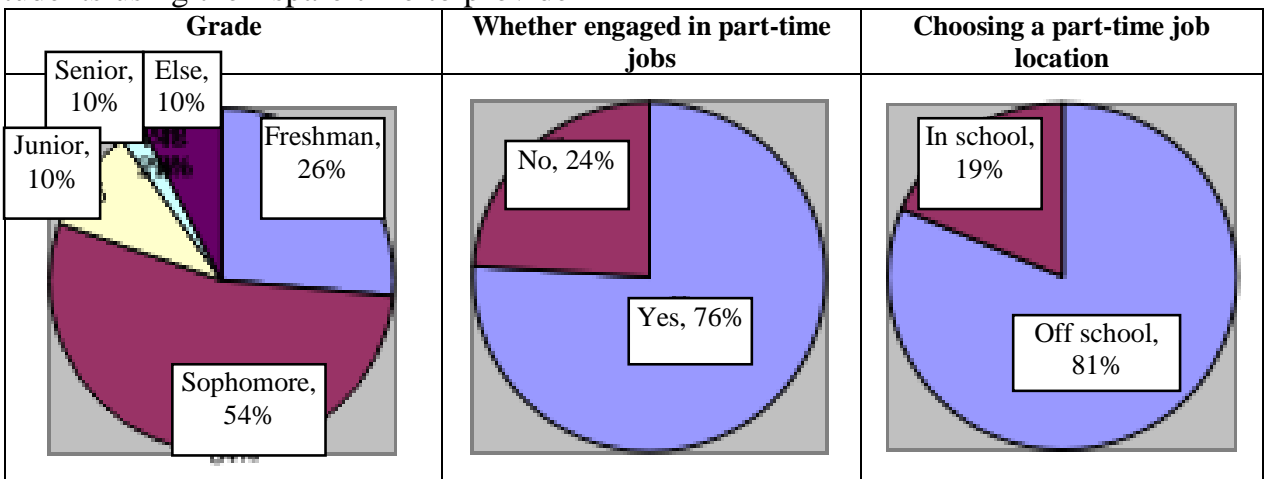

Fig. 1. Distribution of survey sample indicators.

For college students, their part-time jobs may not only be for the purpose of making money, but hope to obtain financial and psychological satisfaction through their effective labor. The survey results ("Fig. 2")show that $56 \%$ of college students are engaged in part-time work to cultivate their personal abilities and improve their personal standards, $55 \%$ of them want to reduce the financial burden, $53 \%$ of them want to increase labor and get remuneration for enterprises and other employers. The survey ("Fig. 1") found that more than $50 \%$ students chose to engage in part-time activities in their sophomore year, and college students engaged in part-time jobs accounted for $76 \%$ of the total number of people surveyed, and $81 \%$ of them took part-time jobs outside the school. However, the current laws of China do not provide enough protection for the vulnerable group of part-time college students and their role is limited, so that the interests of this group can't be effectively guaranteed. 
online part-time jobs. Few people choose industries with high intellectual requirements linked to professions.

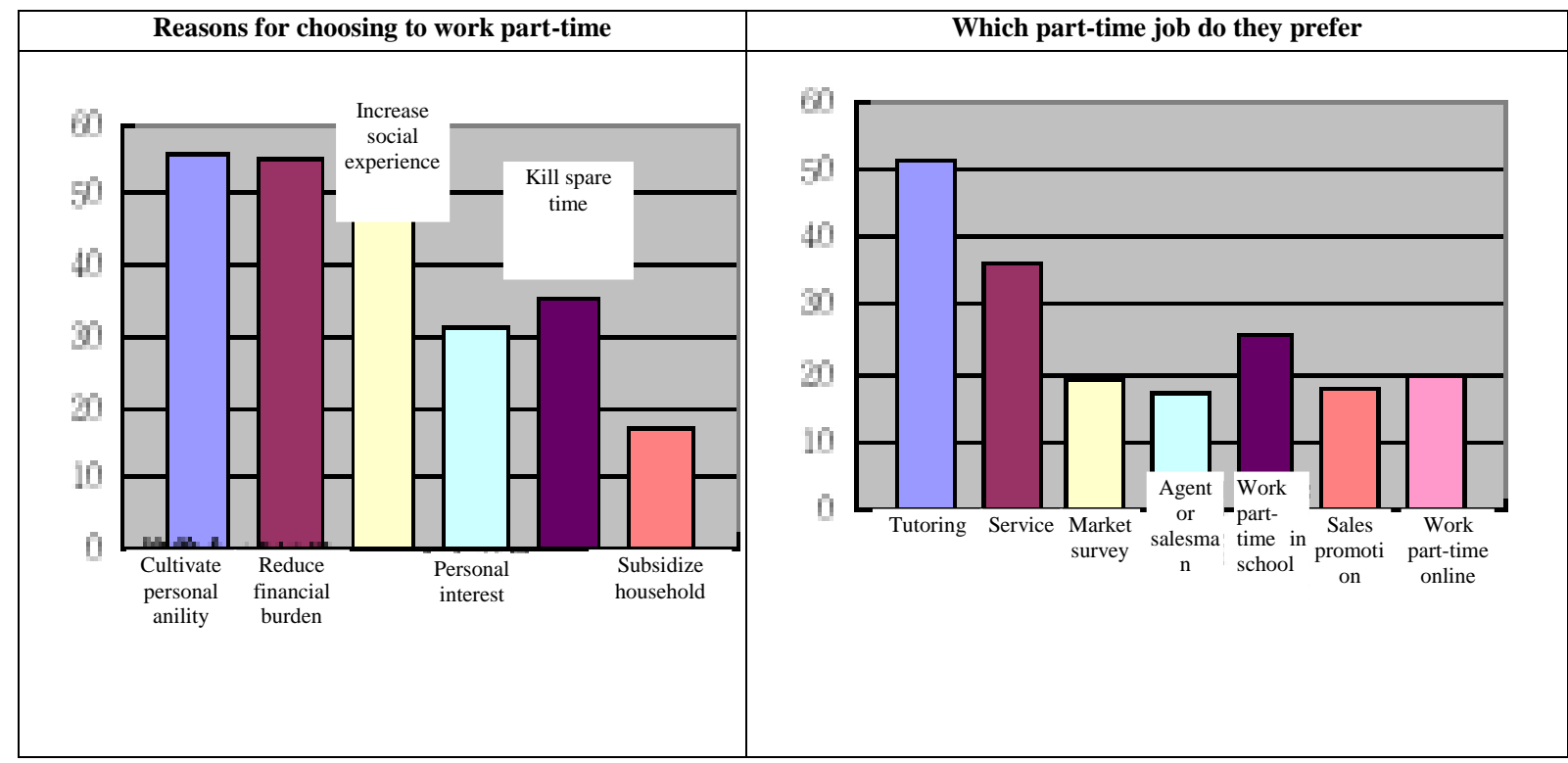

Fig. 2. Reasons and types of college students taking part-time jobs.

After the survey, it was found that except for a small number of college students who want to reduce the burden on their parents through part-time work due to family difficulties, most of them want to be independent through their own efforts, save capital for the future, make themselves more confident and increase social experience.

\section{B. Survey method and scope}

In this survey, questionnaires were used to collect data, and large-scale determination and small-scale random sampling were used to select respondents. A total of some college students from three universities (Shandong University of Political Science and Law, Qingdao University, Qingdao University of Technology) were selected to form the sample of this investigation. Actually, 300 questionnaires were issued, 278 valid questionnaires were recovered, and the effective recovery rate was $92.7 \%$.

\section{THE CURRENT SITUATION OF THE}

\section{INFRINGEMENT OF PART-TIME COLLEGE} STUDENTS' LABOR RIGHTS AND INTERESTS ${ }^{1}$

According to the survey ("Fig. 3"), college students' part-time jobs are mainly infringed on the rights and interests of the following aspects: $38 \%$ of the students report that they have been owed wages by their employers, $11 \%$ of them have been asked for a deposit

\footnotetext{
1 Note: If the sum of the proportions exceeds $100 \%$, it is a
} multiple choice question. at random, $3 \%$ of students report being abused by their employers at will, and $16 \%$ of the students do part-time jobs online and are scammed by their employers, and their rights and interests are not protected.

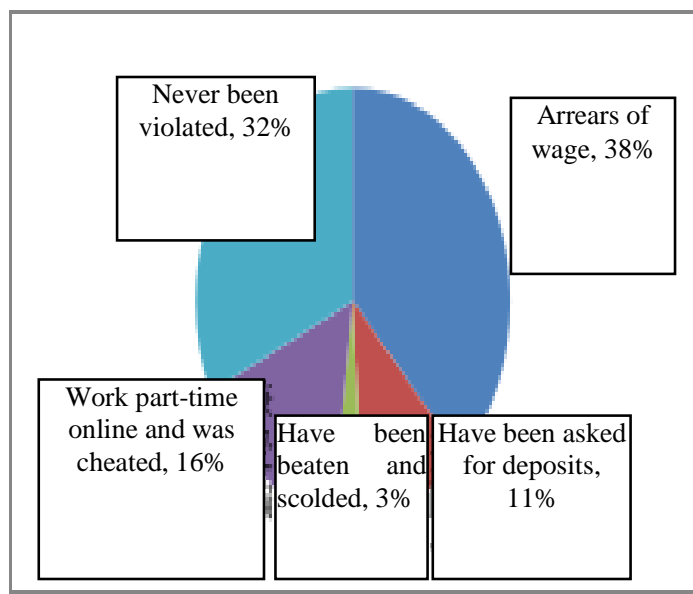

Fig. 3. Types and proportions of injured rights and interests of parttime college students.

\section{REASONS FOR THE VIOLATION OF LABOR RIGHTS OF PART-TIME COLLEGE STUDENTS}

\section{A. Some recruitment information has low authenticity}

Various recruitment advertisements can now be seen everywhere on the university campus, including some false advertisements. Frequently, college students just get in touch with society and have a simple mind, 
thinking that they will be rewarded as long as they work hard. Regarding the source of part-time information ("Fig. 4"), 44\% of students said that they received parttime information from campus posters, $19 \%$ were introduced by intermediaries, and $14 \%$ obtained information from school officials. However, in the questionnaire, some students reported that their school did not train their students for part-time work and employment, which made them and the students around them blindly choose and be easily violated. However, various institutions in the society are mixed, and some lawbreakers use the weaknesses of college students' inexperience in the world, simple thinking and ignorance of rights protection to set various traps for college students, so that the legitimate rights and interests of college students are repeatedly violated. The survey found that $73 \%$ of college students were infringed during part-time work, and their legal rights were not guaranteed, of which $68 \%$ came from intermediary companies and $32 \%$ were from employers.

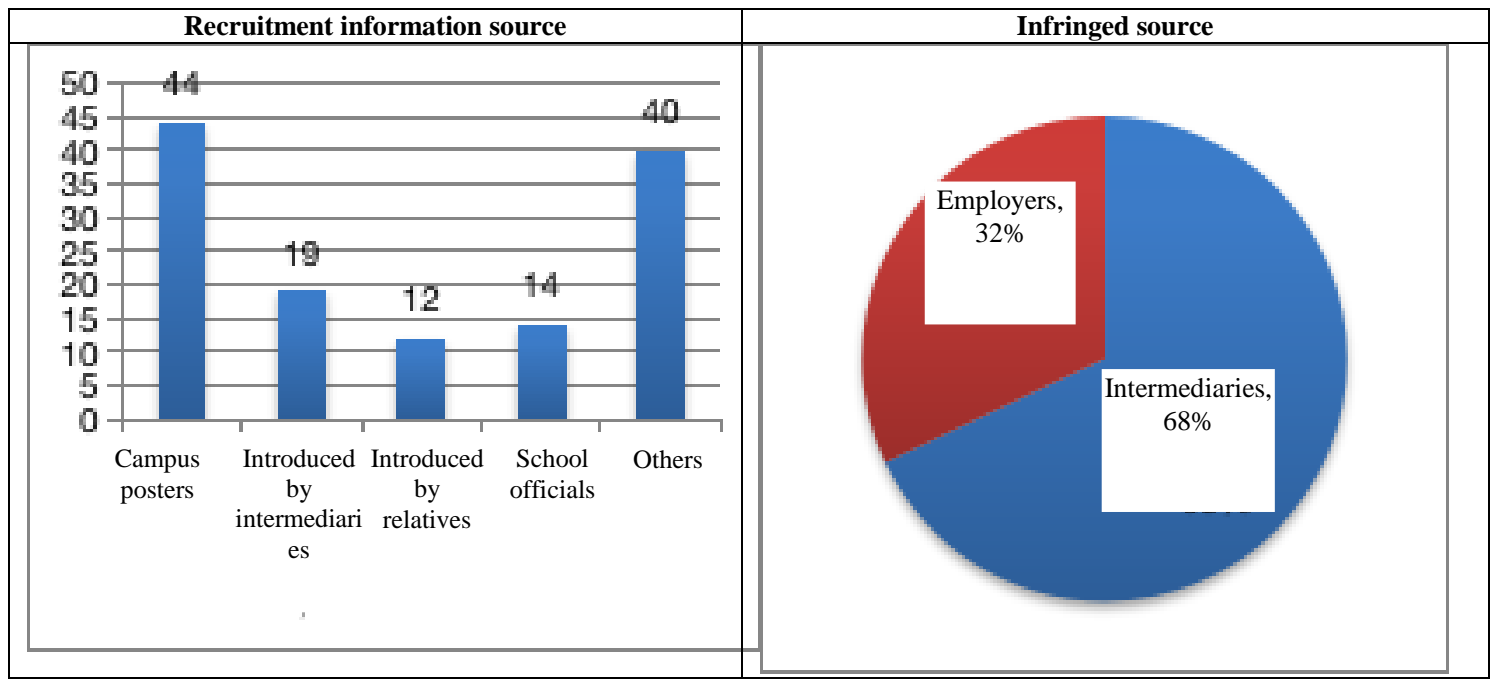

Fig. 4. Recruitment information and sources of infringement.

\section{B. Part-time college students have low self-protection awareness}

1) College students are not alert to intermediary companies and employers

According to investigations ("Fig. 5"), most students are not very vigilant about the legality of intermediary companies and employers when looking for part-time work, and they lack awareness of rights protection after infringement. Specifically, before establishing labor relations with intermediary companies or employers, few students will confirm their legality. According to the survey, only $15 \%$ of the students will confirm the legality of the institution every time, $23 \%$ and $48 \%$ of the students occasionally and often confirm the legality, and $14 \%$ of them do not have the concept of confirming the legitimacy and never sign the contract after confirming the legitimacy of the employer.

After their own rights and interests were damaged, only $10 \%$ of the students chose to complain to the relevant departments or use legal means to solve it, $80 \%$ of the students chose to bear the losses themselves, and $10 \%$ of the students chose to use other means to solve the problem. And a further investigation of some students who chose to suffer losses themselves found that this group of students had thought of protecting themselves through legal channels before choosing to suffer losses, however, the lack of infringement evidence in their hands, the excessively complicated litigation procedures, and the high litigation costs had dispelled their idea of using legal methods. Moreover, their losses were not too large. Compared with litigation costs, it was relatively cost-effective to bear the losses themselves. In addition, some students said that they didn't know which department to report to, so they chose to bear the losses themselves. 


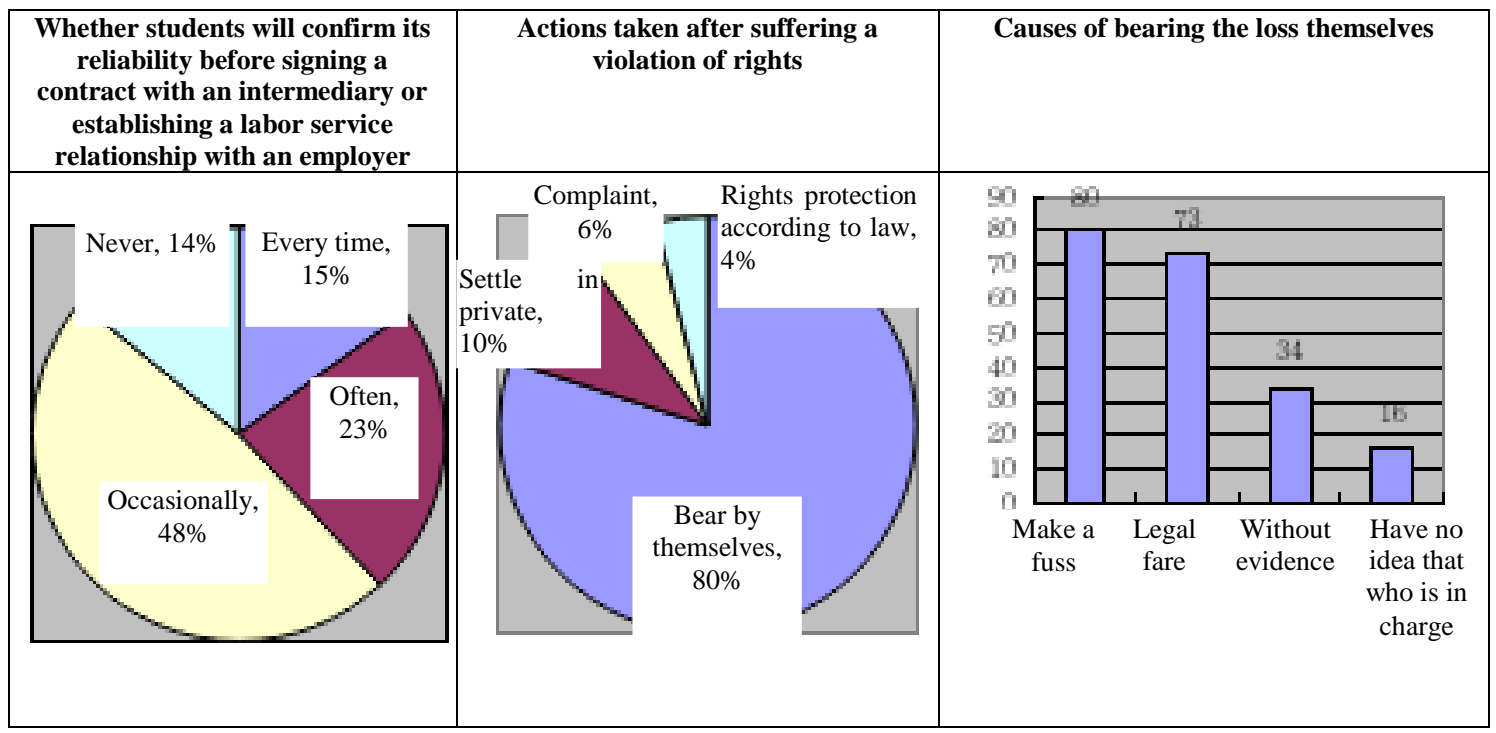

Fig. 5. Student's performance before and after suffering infringement.

2) Some part-time college students are not strong in contract signing

The survey ("Fig. 6")also found that college students often don't pay attention to sign labor agreements or labor contracts with employers or intermediary agencies when establishing labor relations.
Although $61 \%$ of the respondents said that they often sign contracts with employers, 38\% said they only signed occasionally or never signed contracts, and a large part of the respondents thought that it was not necessary to sign labor contracts, which was too small do.

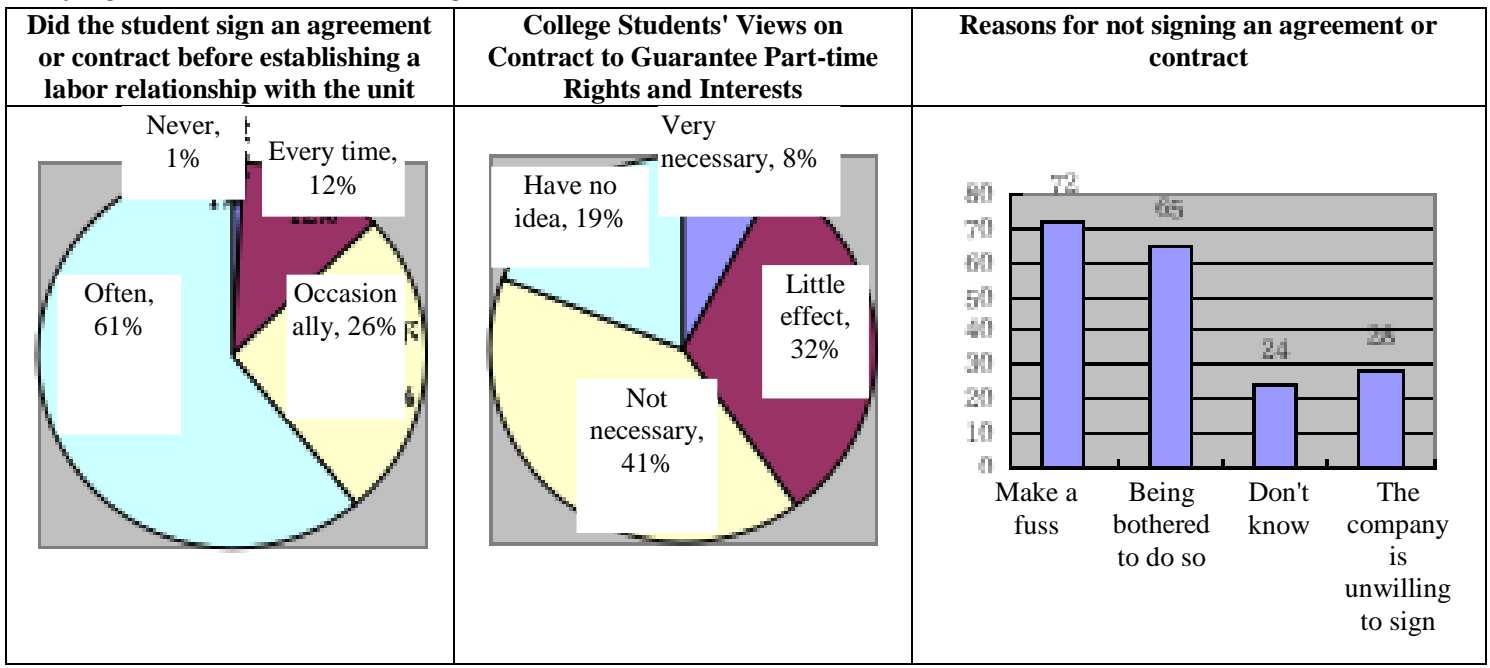

Fig. 6. Attitudes and reasons for signing a contract when working part-time.

Faced with the difficulties encountered in part-time work, students generally expressed the hope that they wanted to get help from schools and professional institutions, that is, they hoped that schools would set up part-time guidance institutions to facilitate effective training of students in part-time work and employment (accounting for $76 \%$ of the total number of respondents). In addition, they also hope that enterprises and government departments can strengthen supervision, effectively crack down on illegal intermediaries and employers, and provide strong protection for the rights and interests of part-time college students.

3) Binary absence of security awareness: college students' self and schools

The group of college students has always lived in the ivory tower jointly constructed by parents and schools, whether in high schools or colleges. They rarely face the society and don't understand the social rules in the workplace. When engaging in part-time activities, most students follow the arrangements of 
intermediaries and employers, and few people will actively plan their part-time work. Moreover, most parttime jobs don't require intelligence, just simple manual labor, and there is little room for college students to exert their abilities and knowledge.

As the main life activity place for college students, schools should not only perform the function of teaching and educating people, but also teach college students to be conduct themselves and guide college students to learn some basic social rules. When parttime work has become a trend on campus, schools should pay attention to it and give sufficient attention and guidance to part-time students to help them complete the harmonious integration of campus life and workplace work.

\section{INSUFFICIENT LEGAL PROTECTION OF LABOR RIGHTS FOR PART-TIME COLLEGE STUDENTS}

Since the former State Education Commission and the Ministry of Finance jointly issued a document requesting colleges and universities to take the workstudy activities as "supporting measures for university reform" and "important daily activities in schools" in September 1993, the market for university students' work-study programs is expanding and enriching. [1]

\section{A. The subject of arbitration is unfit}

So far, China basically applies the protection of civil law to the group of part-time college students, and treats it as an employment relationship or labor relationship. What is obvious is that the adjustments in civil law adhere to the principles of "autonomy of will" and "equality and freedom". Therefore, the relevant departments will not interfere too much in the contracting actions between equal subjects, which is extremely disadvantageous to part-time college students who are in a weak position during the contracting process. Therefore, when students encounter infringements such as employers' arrears of wages, arbitrary collection of security deposits, and arbitrary beatings, they can't seek supervision and relief from relevant labor security departments like ordinary workers who have concluded contracts, nor can they apply for labor arbitration from labor arbitration institutions to protect themselves. They can only apply to the people's procuratorate for mediation or to file a civil suit with the people's court in accordance with the provisions of the civil law and the civil procedure law. The survey results show that when part-time college students encounter employers infringing their rights and fail to negotiate, only $10 \%$ of them choose to complain to the administrative departments of labor, industry and commerce, public security or file a mediation with the labor arbitration institution, $80 \%$ of them choose to bear the losses themselves and $10 \%$ choose to use other means to solve the problem. The reason for this is mainly because it is often difficult for labor arbitration institutions to resolve such disputes, and for college students, the cost of filing civil litigation is too high and they often can't afford. In addition, the waiting process for civil litigation is too long. Even if they file a complaint with the administrative departments of labor, industry and commerce, public security, etc., these departments will also off the docket in accordance with the provisions of Article 12 [2] of the "Opinions of the Ministry of Labor 1995"; if the employer doesn't engage in illegal operations or frauds, the industry and commerce administration and the public security department will also be unable to help the part-time college students due to the limitation of their powers.

\section{B. The absence of labor laws to protect such employment attributes of part-time college students}

First of all, college students take part-time jobs in their spare time and their working hours are flexible. Most part-time jobs take place on holidays or weekends. Neither the full-time employment regulations stipulated in the labor law nor the part-time employment regulations can be applied for its adjustment. According to the survey, $87 \%$ of the respondents had an average daily working time of less than 8 hours, but few students had a daily working time of less than 4 hours. However, most scholars now believe that the behavior of students taking part-time work after school hours (within 4 hours of daily working hours, if the cumulative weekly working time doesn't exceed 24 hours) is adjusted by the part-time employment regulations of the Labor Contract Law. ${ }^{2}$ However, there is a difference between college students' part-time employment and part-time employment: part-time employment is guaranteed in social insurance, and college students can't participate in social insurance because they are in school.

Secondly, college students working part-time outside schools can't be adjusted according to labor dispatch. The Labor Contract Law stipulates that labor dispatch units should sign labor contracts with workers for a fixed period of more than two years, while parttime college students have uncertainty in time and space, and it is impossible to sign such a relatively fixed labor contract with the labor dispatch unit. Part-time work-study for on-campus students is not
considered as employment; students may not sign labor contracts without establishing labor relations. 


\section{IMPROVING THE LEGAL PROTECTION OF PART-TIME COLLEGE STUDENTS' LABOR RIGHTS AND INTERESTS}

\section{A. The identification of the subject of part-time college students' labor relationship - a special labor relationship}

For the legal relationship formed by college students in the course of part-time work, most scholars and experts currently apply the Article $12^{3}$ of the "Opinions of the Ministry of Labor 1995". But in the author's opinion, such view is debatable.

First, in 2007, the Ministry of Education and the Ministry of Finance jointly promulgated the "Administrative Measures on Work-study Aid for College Students". According to the measures, parttime work refers to the social practice activities in which students use their after-school time to obtain legal remuneration through their own legal labor, which is used to improve learning and living conditions. From the explanation of this method, it can be seen that parttime work only refers to the organization of the school, and doesn't include the behavior of students working privately outside the school. Therefore, part-time college students don't belong to the category of workstudy program.

Second, Article 1 of the "Notice on Matters Related to the Establishment of Labor Relations" (hereinafter referred to as the "Notice") issued by the former Ministry of Labor and Social Security in 2005 reflects the "subordinate" characteristics of labor relations and should be considered as labor relations.

Judging from the current "Labor Law" for the qualification of citizens in employment, all citizens who are 16 years of age and capable of working in China have the legal qualification to become workers. The "Explanation on Several Provisions of the" Labor Law " issued by the former General Office of the Ministry of Labor is only to exclude civil servants and staff of business organizations and social organizations that implement the civil service system, as well as agricultural workers, active-duty military personnel and home carer, from the application of the labor law, and doesn't exclude college students. According to the rule of "what is not forbidden by the law is doable", college students are eligible to establish labor relations. In judicial practice, there are also many judgments

If the employing unit doesn't conclude a written labor contract but at the same time meets the following conditions, the labor relationship is established: (1) the employing unit and the laborer meet the main qualifications prescribed by laws and regulations; (2) various labor regulations and systems formulated by the employer in accordance with the law are applicable to the laborer, and the laborer is subject to the labor management of the employer and engages in paid labor arranged by the employer; (3) the labor provided by the laborer is a part of the employer's business confirming the qualifications of college students as labor subjects.

Based on the above analysis, the author believes that all part-time college students who are over 16 years old and have the ability to work have the main qualifications for establishing labor relations and entering into labor contracts, but given that their working hours are different from full-time and parttime employment, they should be treated as a special subject.

\section{B. Perfection of the specific system for the legal protection of labor rights for part-time college students}

Because part-time college students have special status and working hours, they should be separated from the civil law and included in the protection scope of the labor law as a special subject. In legislation, it is necessary to highlight the uniqueness of the part-time protection of college students in enterprises, but also to connect with the basic structure of the current legal system. Based on this concept, the author believes that led by the Ministry of Human Resources and Social Security, in conjunction with the Ministry of Finance, the Ministry of Education and other departments, it is possible to formulate the "Measures for the Protection of the Rights and Interests of Part-time Labor of College Students", in which the following aspects can be stipulated.

\section{1) Scope of application}

In view of the flexibility and uncertainty of college students' part-time jobs outside the school, the legislation can refer to the provisions of Article 1 of the Notice to limit the scope of application to the part-time labor relationship with relative stability and subordination established between part-time college students and employers. The temporary and accidental employment of part-time college students by employers and the legal relationship established between part-time college students and non-unit employers due to parttime employment are still handled in accordance with the labor service relationship or employment relationship, which are also applicable to the civil law adjustment. But it must be clearly stipulated that the form of labor dispatch is not applicable to the part-time job of college students.

\section{2) Restrictions on the scope of part-time labor}

In order to protect the physical and mental health of college students, legislation should clearly restrict college students from taking part-time jobs in the following places and types of work: KTV, nightclubs, bathing centers and other entertainment places; poisonous and harmful, flammable and explosive, the fourth-level manual labor intensity stipulated by the state and other labors with hidden safety hazards; other 
labors that affect the physical and mental health of college students.

\section{3) Working hours limit}

Although college students take part-time jobs in their spare time, their main business is still studying. In order to guarantee the necessary study time for college students, it should be stipulated that the cumulative working hours of part-time college students in a semester shall not exceed 80 hours; during winter and summer holidays and statutory holidays, the working hours system prescribed by the current labor law shall apply. The general provisions of the labor law apply to part-time college students who work for extended working hours.

\section{4) Special work injury insurance}

Social insurance is a legal system in which the state or society provides employed workers with material assistance to maintain their basic life needs when they encounter specific difficulties. The college students working part-time in the enterprise can't be counted in the category of employment, so they can't participate in the existing social insurance. However, in the course of part-time work, it is inevitable that accidental injuries will be encountered due to work reasons. In order to urge employers and intermediaries to perform part-time college students' safety guarantee obligations, the following provisions may be made in legislation:

First, in order to prevent accidents from occurring at the source, employers and intermediaries should provide part-time college students with labor safety and health education to prevent accidents.

Second, based on the background that college students can't and shouldn't participate in social insurance, legislation can be matched with the special labor relationship of college students working parttime. It shall be undertaken by the current agency for work injury insurance, and a special work injury insurance fund shall be established in addition to the work injury insurance fund. The fund is raised through employer contributions and government financial subsidies. Insured employers can use the monthly salary of college students as the base, calculate the amount of payment based on the standard labor-related workrelated injury rate of $70 \%$ to $80 \%$, and then pay $80 \%$ of the amount paid for part-time college students, and the remaining $20 \%$ can be subsidized by the government.

\section{5) Wage guarantee}

Although only precious few part-time college students use part-time earnings as their main source of living, due to respect for labor, part-time college students should also be given the necessary due remuneration. The legislation should clearly stipulate the hourly minimum wage for college students working part-time in enterprises. This standard can be determined from $70 \%$ to $80 \%$ of the minimum standard for part-time working hours, and the general provisions of the labor law apply for wage payments.

For other aspects, such as labor safety and health standards, supervision and inspection, and labor dispute handling, the general provisions of the labor law still apply.

\section{CONCLUSION}

College is an important stage in the establishment of college students' three reflections, and it is also a critical period for their transition from university to society. At this time, engaging in part-time work is an inherent requirement for the comprehensive and healthy development of their body and mind, which plays a vital role in improving their personality and character. Whether they are treated fairly and whether they experience credibility directly affects whether they are the maintainers or devastators of social order in society in the future. In today's part-time market, the reliability of recruitment information is not guaranteed, and employers arbitrarily owe wages and delay working hours, resulting in frequent violations of the rights of part-time college students. Under such circumstances, it is particularly important to improve various guarantee mechanisms to ensure that part-time college students' guarantee work enters a normal and orderly track. Safeguarding the lawful rights and interests of college students during part-time work is not only a guarantee for the legitimate rights and interests of citizens, but also an important manifestation of social civilization and progress.

\section{References}

[1] Li Xiandong. Guideline to legal resolution of labor disputes [M]. Beijing: Machinery Industry Press, 2004: 1-68. (in Chinese)

[2] Wen Qinghong, Song Xiaobo. Analysis of legal issues related to work-study programs for college students [J], Journal of Tianjin Municipal Law Management Cadre College, 2009 (1). (in Chinese)

[3] Tian Silu, Jia Xiufen, Research on Contracted Labor - Theory and Practice of Japan [M]. Law Press - China, 2007. (in Chinese)

[4] Han Guangyao, Very Part-time Documentary of Chinese University Students [M], Beijing: China Pictorial Publishing House, 2005. (in Chinese)

[5] Li Qian, Motivation Analysis of Part-time Jobs of College Students [J], Journal of Chongqing University of Science and Technology, 2008 (1).(in Chinese)

[6] Tang Zhongiiang, Protection and Relief of University Students' Part-Time Work [J], Journal of Shandong Youth League School, 2009 (1). (in Chinese)

[7] Liu Zhengfa, He Jixiu, Research on the Current Phenomenon of Part-Time Work Among College Students in China [J], Heilongjiang University Research, 2005 (7). (in Chinese)

[8] Liu Wenhua, Research on Legal Issues of Part-time Labor Relations [J], China Labor, 2004 (4). (in Chinese)

[9] Wang Qian, Defects and Improvement of Part-time Employment Regulations - Taking McDonald's Low Salary Incident as an Example [J], Law Science, 2007. (in Chinese) 